\title{
The management of bladder incontinence in the elderly
}

\author{
A Verdino \\ From de Senectute: Age and Health Forum \\ Catanzaro, Italy. 5-7 December 2009
}

Bladder incontinence is present in all age groups. But risk factors such as increasing age, degenerative diseases, intervention due to prostatic diseases, metabolic or neurological disorders which are typical of an advanced age result in a challenging reality to face.

It's a widespread custom to consider incontinence as a disorder or a natural consequence of aging; on the contrary, it is a disease that responds well to various treatments. Urinary incontinence of the elderly is a complex issue because it determines significant changes in personal lifestyle causing serious psychological states of depression. Losing control of our body basic functions can lead busy people to lifestyles never before considered, often self-limiting. The item requires an integrated approach to the various professions in order to allow people the best life quality.

Good advice and information can help to handle and resolve one of the main causes of hospitalization or long stays in healthcare facilities.

- Convenient online submission

- Thorough peer review

- No space constraints or color figure charges

- Immediate publication on acceptance

- Inclusion in PubMed, CAS, Scopus and Google Scholar

- Research which is freely available for redistribution 